\title{
Avantaj ve Dezavantajlarıla İzaha Davet Müessesesi
}

\author{
Selçuk BUYRUKOĞLU*, Ekrem TOPARLAK ${ }^{* *}$ \\ ÖZ
}

Mükellefler ve vergi idareleri kimi zaman uyuşmazlık yaşayabilirler. Bu uyuşmazlıklar mükelleflerden kaynaklanabileceği gibi vergi idarelerinden de kaynaklanabilir. Uyuşmazlıkların giderilmesinde vergi idarelerinin ve mükelleflerin ilk tercihi genellikle idari aşamada çözüm yollarıdır. Çünkü devletin vergi gelirleri biran önce hazine kasasına girmiş olurken, mükelleflerde idari çözüm yollarının sağlamış olduğu avantajlardan faydalanacaktır. Bu noktada kazanan hem devlet hem de mükellef olacaktır. İzaha davet müessesesi de vergi uyuşmazlıklarının idari çözüm yollarından bir tanesidir. Bu uygulama ile vergi ziyaına sebebiyet veren mükellefler, vergi uyuşmazlıklarının vergi incelemesine başlanılmaması ve takdir komisyonuna sevk işleminin yapılmamış olması koşuluyla vergi idareleri tarafından ilgili ziyaa ilişkin açıklama yapmaya davet edilirler. Bu çalışma da, izaha davet uygulamasının tanımı, hukuki dayanağı, amacı, kapsamı ve işleyişine yer verildikten sonra avantaj ve dezavantajlarına değinilecektir.

Anahtar Kelimeler: İzaha Davet, Vergi Uyuşmazlığı, İdari Çözüm Yolu, Avantaj, Dezavantaj.

JEL Sınıflandırması: K34.

\section{Invitation to View Method with Advantages and Disadvantages ABSTRACT}

Taxpayers and tax administrators sometimes may experience tax dispute. These disputes may arise from the taxpayers as well as from the tax administrators. In resolving tax disputes, tax administrators and tax payers are the first, usually administratively, solution. Because while the tax revenues of the state are possible entered into the state treasury, the taxpayers will benefit from the advantages of administrative solutions. The state and taxpayer herein will be the winner. Invitation to view is one of the administrative remedies for tax disputes. With this practice taxpayers who have caused tax evasion penalty are invited by tax administrators to make a declaration on the condition that the tax examination of the tax disputes is not started and the dispatch process has not been done to the discretion comission. In this study, advantages and disadvantages will be addressed after the definition, legal support, purpose, scope and mechanism of Invitation to view.

Keywords: Invitation to View, Tax Dispute, Administrative Solution Way, Advantage, Disadvantage.

JEL Classification: K34.

\footnotetext{
* Yrd. Doç. Dr., Niğde Ömer Halisdemir Üniversitesi, İIBF, Maliye Bölümü, selcuk349@ @otmail.com, https://orcid.org/0000-0003-4335-1575

**Arş. Grv., Niğde Ömer Halisdemir Üniversitesi, İ̈BF, Maliye Bölümü, ekremtoparlak@gmail.com, https://orcid.org/0000-0002-2136-2962
} 


\section{GÍRİŞ}

Kamu gelirlerinin büyük bir kısmını kapsayan vergiler mükellefler açısından bir yükümlülük iken devlet açısından gelir kaynağıdır. Mükelleflerin yükümlülüklerini yerine getirmesi, devletinde vergiyi doğuran olay neticesinde vergi talep etmesi günümüz dünyasında olağan bir süreç olarak kabul edilmektedir. Ülkemizde de vergiyi doğuran olayın gerçekleşmesiyle başlayan vergilendirme süreci, ilgili kanunlar dâhilinde devletin vergiyi tahsil etmesi ile sonuçlanmaktadır. Bu süreç içerisinde; devlet mükellefin ödeyeceği vergi miktarını hesaplar, ödenecek vergi miktarını mükellefe bildirir ve mükellefin ödenecek vergiye herhangi bir itirazı olmaması durumunda vergi kesinleşir. Olması gereken veya beklenen süreç bu iken, bazı durumlarda mükellefler ile vergi idareleri arasında uyuşmazlıklar ortaya çıkabilmektedir. Uyuşmazlıkların ortaya çıkışında mükelleflerde vergi idareleri de taraf olabilir. İlgili uyuşmazlıklar ise idari (barışçl) veya yargısal çözüm yöntemleriyle çözümlenmeye çalışılmaktadır. Vergi hukukunda uyuşmazlıkların idari çözüm yöntemleri hataların düzeltilmesi, pişmanlık ve 1slah, cezalarda indirim ve uzlaşma olarak kabul edilmiştir (İşbilir, 2008:3). İzaha davet müessesesi de vergi uyuşmazlıklarının idari çözüm yöntemlerinden bir tanesidir. Bu müessese ile vergi ziyaına ilişkin cezalarda vergi incelemesi başlamadan ve takdir komisyonuna sevk işleminin yapılmadan mükellefe izah (açıklama) yapma hakkı tanınmaktadır.

Uygulamanın hayata geçirilebilmesi için VUK'un 370 inci maddesinin Maliye Bakanlığına verdiği yetkiye istinaden 482 Sıra No.lu Vergi Usul Kanunu Genel Tebliği ile izaha davetin kapsamı ve şekli, ön tespitin niteliği, izaha daveti yapacak ve yapılan izahı değerlendirecek merciler, davet yapılacaklar, yapılan izahta kullanılacak bilgi ve belgeler ile uygulamaya ilişkin diğer usul ve esaslar belirlenmiştir. Bu çalışma ile ilgili mevzuatta yer alan düzenlemelere ve izaha davet uygulamasının avantaj ve dezavantajlarına değinilecektir.

\section{HUKUKİ MEVZUAT İÇERİSINDE IZAHA DAVET MÜESSESESİ}

\section{1. İzaha Davet Kavramı, Hukuki Dayanağı ve Amacı}

İzah, genel olarak açıklama anlamına gelmektedir. Vergisel boyutta ise, Maliye Bakanlığı'nın belirli konular dâhilinde vergi ziyaina sebebiyet veren mükelleflere cezai müeyyideler uygulanmadan açıklama hakkı verilmesidir. Yani, izaha davet müessesesi, verginin ziyaa uğradığına delalet eden emareler bulunduğuna dair yetkili merciler tarafından yapılmış ön tespitlerle ilgili olarak aynı merciler tarafından mükelleflerden açıklama talep edilmesidir. ${ }^{1} \mathrm{Bu}$ müessese ile yapılan değerlendirmeler sonucunda vergi ziyaına sebebiyet vermediği anlaşılan mükelleflerin konuyla ilgili vergi incelemesine veya takdire sevk edilmesini önlemekte, vergi ziyaına sebebiyet verildiği durumlarda ise belirli şartlar dâhilinde indirimli ceza uygulanmak suretiyle mükellefleri daha ağır müeyyidelerden korumaktadır.

İzaha davet kavramı, 09/08/2016 tarihli ve 29796 sayıl Resmi Gazete'de yayımlanan 6728 sayılı "Yatırım Ortamının İyileştirilmesi Amacıyla Bazı Kanunlarda Değişiklik Yapılmasına Dair Kanun" ve 213 sayılı Vergi Usul Kanunu'nun mülga 370 inci maddesinde yer almaktadır. 6728 sayılı kanunun isminden de anlaşılacağı üzere, izaha davet kavramı ülkemizdeki yatırım ortamının iyileştirmek adına gelen bir uygulamadır. Ayrıca, 482 Sıra No.lu Vergi Usul Kanunu Genel Tebliğinin 1. maddesinde de "Getirilen bu düzenleme ile İdare ve mükellefler arasındaki uyuşmazlıkların azaltılması, İdarenin zamanını daha etkin ve verimli alanlara hasretmesi, olayların gerçek mahiyetinin tespit edilmesine mükelleflerce daha çok katkıda bulunulması ve bu sayede vergiye gönüllü uyumun artırılması amaçlanmaktadır."

\footnotetext{
${ }^{1}$ Vergi Sirküleri No: 2017/87.
} 
denilerek ilgili düzenlemenin sadece yatırım ortamını iyileştirmek için konulmadığı anlaşılmaktadır. Bu nokta da izaha davet kavramı, hem ülke ekonomisine makro anlamda katkı sağlayacak hem de Maliye Bakanlığı'nın etkin bir şekilde çalışmasına imkân tanıyacaktır.

\section{2. İzaha Davetin Kapsamı}

İzaha davetin kapsamını belirleme yetkisi Vergi Usul Kanununun 370 inci maddesinin dördüncü fikrası ile Maliye Bakanlığına verilmiştir. Bu kapsamda hangi konularla ilgili olarak izaha davet müessesesinin uygulanacağı Maliye Bakanlığı tarafından belirlenecektir. Bu yetki kapsamında Maliye Bakanlığı izaha davetin kapsamını ${ }^{2} 482$ Sira No.lu Vergi Usul Kanunu Genel Tebliğinin 2. maddesinde aşağıdaki konular ile sınırlamıştır.

- Ba-Bs bildirim formlarında yer alan bilgilerin analizi sonucunda mükelleflerin

- Kredi kartı satış bilgileri ile katma değer vergisi (KDV) beyannamelerinin karşılaştırılması sonucunda mükelleflerin

- Yıllık beyannameler ile muhtasar ve prim hizmet beyannamelerinin karşılaştırılması sonucunda mükelleflerin

- Çeşitli kurum ve kuruluşlardan elde edilen bilgiler ile asgari ücret tarifelerinin karşılaştırılması sonucunda mükelleflerin

- Y1llık gelir ve kurumlar vergisi beyannameleri üzerinde yapılan indirimleri, kanuni oranları aşan mükelleflerin

- Dağıttığı kâr üzerinden tevkifat yapmadığı tespit edilenlerin

- Geçmiş y1l zararlarının mahsubu yönünden mükelleflerin

- İştirak kazançlarını ilgili hesapta göstermeyen mükelleflerin

- Kurumlar vergisi kanununun 5/1-e maddesindeki istisna ile ilgili olarak mükelleflerin

- Örtülü sermaye yönünden mükelleflerin

- Ortaklardan alacaklar için hesaplanması gereken faizler yönünden mükelleflerin

- Ortaklık hakları veya hisselerini elden çıkardıkları halde beyanda bulunmayan limited şirket ortaklarının

- Gayrimenkul alım/satım bedelinin eksik beyan edilmiş olabileceğine dair haklarında tespit bulunanların

- Gayrimenkullere ilişkin değer artışı kazançları yönünden mükelleflerin

- Gayrimenkul sermaye iratların beyan etmeyen veya eksik/hatalı beyan eden mükelleflerin izaha davet edilmesi mükelleflerin

- Sahte veya muhteviyatı itibariyla yanıltıc1 belge kullanılması durumunda

\section{3. İzaha Davet Sürecinin İşleyişi}

\subsection{1. Ön Tespit ve Şartları}

Ön tespit kavramına 482 Sira No.lu Vergi Usul Kanunu Genel Tebliğinin 3. maddesinde yer verilmiştir. Buna göre ön tespit, vergi kanunlarının verdiği yetki kapsamında vergi incelemesi yapmaya ve/veya mükellefler veya mükelleflerle muamelede bulunan diğer gerçek ve tüzel kişilerden bilgi toplamaya yetkili kılınanlar tarafından doğrudan veya dolaylı olarak elde edilen bilgi, bulgu veya verilerin İzah Değerlendirme Komisyonu'na intikal ettirilmesi

\footnotetext{
2 İzaha davet kapsamındaki konulara ilişkin ayrıntılı açıklamalar 482 Sıra No.lu Vergi Usul Kanunu Genel Tebliğinde yer almaktadir.
} 
neticesinde, mezkûr komisyon tarafından verginin ziyaa uğramış olabileceği ve mükellefin izaha davet edilebileceği yönünde yapılan tespiti ifade etmektedir. Ön tespitin yapılabilmesi için;

- Verginin ziyaa uğradığına delalet eden emareler bulunması,

- Yetkili merciler tarafından ön tespitin yapılmış olması,

- Vergi incelemesine başlanılmamış (ön tespitin ilgili olduğu konuya ilişkin olarak; mükellef nezdinde bir vergi incelemesine başlanılmamış olmasını veya mükellefin takdir komisyonuna sevk edilmemiş olmasını ifade eder.),

- Takdir komisyonuna sevk işleminin yapılmamış olması ve ihbarda bulunulmamış olması (tespit tarihine kadar ihbarda bulunulmamış olmasını ifade eder.),

gerekmektedir. Aksi durumda mükellef izaha davet edilmeyecektir.

\subsection{2. İzaha Davet Yazısı}

482 Sira No.lu Vergi Usul Kanunu Genel Tebliğinin 5. maddesine göre, "Komisyon tarafından haklarında ön tespit yapılanlara, gerekli açıklamaların yer aldığı ve bu Tebliğ ekinde yer alan "İzaha Davet Yazısı" VUK hükümleri uyarınca tebliğ olunur."

İzaha davet yazısında aşağıdaki hususlara yer verilir:

- İzaha davet yazısının tebliği tarihinden itibaren 15 gün içerisinde ön tespitle ilgili olarak gerekli izahın yapılması ve yapılan izah sonucu Komisyonca, vergi ziyaina sebebiyet verilmediği ve beyanname verilmesini gerektirir bir durum bulunmadığının anlaşılması halinde söz konusu ön tespitle ilgili olarak vergi incelemesi ve takdir komisyonuna sevk işlemi yapılmayacağı,

- İzaha davet yazısının tebliği tarihinden itibaren 15 günlük süre içerisinde izahta bulunulmaması halinde VUK'un 370 inci maddesinde yer alan indirimli ceza uygulamasından yararlanılamayacağı ve mükellefin vergi incelemesine ya da takdir komisyonuna sevk edileceği,

- İzahın yapıldığı tarihten itibaren 15 gün içerisinde, hiç verilmemiş olan vergi beyannamelerinin verilmesi, eksik veya yanlış yapılan vergi beyanının tamamlanması veya düzeltilmesi ve ödeme süresi geçmiş bulunan vergilerin, ödemenin geciktiği her ay ve kesri için 6183 sayılı Amme Alacaklarının Tahsil Usulü Hakkında Kanunun (AATUHK) 51 inci maddesinde belirtilen nispette uygulanacak gecikme zammı oranında bir zamla (izah zammı) aynı sürede ödenmesi şartıyla vergi ziyaı cezasının ziyaa uğratılan vergi üzerinden \%20 oranında kesileceği,

- İzahın yeterli görülmemesi halinde mükellefin vergi incelemesine ya da takdir komisyonuna sevk edilebileceği,

- $\quad$ Mükellefin, yapacağı izahı desteklemek amacıyla başta defter ve belgeler olmak üzere VUK'un 3 üncü maddesi kapsamında her türlü delili sunabileceği,

- Davet konusu ön tespitle ilgili olarak VUK'un 371 inci maddesinde yer alan pişmanlık hükümlerinden yararlanılamayacağı.

\subsection{3. İzahın Değerlendirilmesi}

Kendisine izaha davet yazısı tebliğ edilenlerin madde hükümlerinden yararlanmaları için tebliğ tarihinden itibaren 15 gün içerisinde yetkili komisyona izahta bulunmaları gerekmektedir. $\mathrm{Bu}$ süre içerisinde ilgili komisyona izahta bulunmayanlar anılan madde hükmünden yararlanamaz. Süresinde yapılan izah, komisyonca en geç 10 gün içinde değerlendirilerek sonuca bağlanır. 
Mükellefin ya ziyaa uğratılmış olabilecek vergi tutarını doğrular nitelikte ya da verginin ziyaa uğratılmadığına ilişkin izahta bulunması durumuna göre yapılacak işlemler farklılık göstermektedir.

\subsubsection{Ziyaa Uğratılmış Olabilecek Vergi Tutarını Doğrular Nitelikteki İzah Üzerine Yapılacak İşlemler}

Haklarında yapılan ön tespite ilişkin olarak, izaha davet yazısında yer verilen ziyaa uğramış olabilecek vergi tutarını doğrular nitelikte vergi ziyaına neden olunduğu yönünde mükelleflerce izahta bulunulması durumunda, izahın yapıldığ 1 tarihten itibaren 15 gün içerisinde hiç verilmemiş olan vergi beyannamelerinin verilmesi, eksik veya yanlış yapılan vergi beyanının tamamlanması veya düzeltilmesi, ödeme süresi geçmiş bulunan vergilerin, ödemenin geciktiği her ay ve kesri için, 6183 sayılı Kanunun 51 inci maddesinde belirtilen nispette uygulanacak gecikme zammı oranındaki izah zammıyla ödenmesi şartlarıyla vergi ziyaı cezası, ziyaa uğratılan vergi üzerinden $\% 20$ oranında kesilir.

\subsubsection{Verginin Ziyaa Uğratılmadığına İlişkin Yapılan İzah Üzerine Yapılacak İşlemler}

\subsection{Yapılan İzahın Yeterli Bulunması}

Haklarında yapılan ön tespite ilişkin vergi ziyaına neden olunmadı̆̆ı yönünde mükellefçe izahta bulunulması üzerine, mükellefin izahının komisyonca yeterli bulunması ve beyanname verilmesini veya vergi beyanının tamamlanmasını gerektirir bir durumun olmadığının değerlendirilmesi halinde, mükellef hakkında söz konusu tespitle ilgili olarak vergi incelemesine ve takdir komisyonuna sevk işlemi yapılmaz.

\subsection{Yapılan İzahın Yeterli Bulunmaması}

Mükellefçe yapılan izahın komisyonca yeterli bulunmaması ve beyanname verilmesini gerektiren bir durumun bulunduğunun değerlendirilmesi halinde bu durum mükellefe bildirilir. Bu bildirim üzerine, izahın yapıldığı tarihten itibaren 15 günlük süre sona ermeden mükellefçe; hiç verilmemiş olan vergi beyannamelerinin verilmesi, eksik veya yanlış yapılan vergi beyanının tamamlanması veya düzeltilmesi, ödeme süresi geçmiş bulunan vergilerin, ödemenin geciktiği her ay ve kesri için, 6183 sayılı Kanunun 51 inci maddesinde belirtilen nispette uygulanacak gecikme zammı oranındaki izah zammıla ödenmesi şartlarıyla vergi ziyaı cezası, ziyaa uğratılan vergi üzerinden \%20 oraninda kesilir.

Yapılan izahın yeterli bulunmamast ve mükellef tarafindan VUK'un 370 inci maddesinde öngörülen işlemlerin gerçekleştirilmemesi durumunda incelemeye veya takdire sevk işlemleri yapilır.

\section{3. İZAHA DAVET MÜESSESESINIIN AVANTAJ VE DEZAVANTAJLARI}

Vergi uyuşmazlıklarının çözümünde idari bir çözüm yöntemi olarak kabul edilen izaha davet müessesesinin bir takım avantajlarının yanında bir takım da dezavantajlara sahiptir. Bu başlıkta öncelikle izaha davetin avantajlarından daha sonra ise dezavantajlarından bahsedilecektir. 


\subsection{Avantajları}

Vergi uyuşmazlıkları idari veya yargısal yollarla çözüme kavuşturulabilmektedir. Devlet veya mükellef yargısal yola başvurmadan önce idari yollara başvurarak bir takım avantajlar elde etmek istemektedir. Yürürlükte bulunan idari çözüm yöntemlerine (uzlaşma, cezalarda indirim, pişmanlık ve 1slah, hata düzeltme) ilave olarak gelen izaha davet müessesesinin de gerek devlet gerekse mükellef açısından bir takım avantajları bulunmaktadır. Özellikle devletin vergilendirmede iktisadilik ilkesini benimsemiş olduğu düşünüldüğünde, uyuşmazlığın yargıya intikal etmeden hazineye intikali arzu edilmektedir. Mükellefler ise kendilerine böyle bir hakkın (şansın) verilmesi neticesinde mükellefiyet kavramına daha sağduyulu yaklaşarak vergi bilincine sahip birer birey olabileceklerdir. İzaha davet uygulamasının mükellef ve devlet açısından avantajlarına aşağıdaki şekilde özetlenebilir.

\section{Mükellef haklarina saygl;}

Mükellef hakları, vergi idaresi tarafından yapılan ve idari bir işlem olan vergilendirme işleminde devlet ile mükellef arasında hukuki ilişkide vergi mükelleflerine tanınan haklardır (Türkay, 2013:153). İzaha davet uygulamasında da devletin vergi ziyaina sebebiyet vermiş mükelleflere bir hak tanıyarak açıklama yapmasına izin vermesi olayı gerçekleşmektedir. Yani devlet direk olarak vergi ziya1 cezası kesmemekte ve mükellefe kendisini izah etme hakkı tanımaktadır. Gelir İdaresi Başkanlığı (GïB) tarafından yayımlanan "Mükellef Hakları Bildirgesi” de Türk Gelir İdaresi'nin mükellef odaklı bir şekilde hareket etmesi açısından önemli bir kaynak niteliğindedir.

Son yıllarda birçok ülkede yayınlanan mükellef hakları bildirgeleri ile mükelleflerin vergisel işlemlerinden doğan hakları ile yükümlülükleri, açık olarak tanımlamaya çalışılmaktadır. Bu şekilde mükelleflerin hak ve yükümlülükleri bütün bireylerin kolaylıkla erişebileceği bir form durumuna getirilmektedir. Burada temel beklenti, mükellef ile vergi idaresi arasında güven ortamının oluşturulup işbirliği sağlanması ve vergi sorunlarının mükellef açısından değerlendirilerek mükellef haklarının açık bir biçimde tanımlanıp, korunmasıdır (Çetin ve Gökbunar, 2010: 26).

\section{Vergiye gönüllü uyum;}

Günümüzde tüm gelir idareleri için önem arzeden gönüllü uyum; mükelleflerin, gelirlerini beyan edip vergilerini eksiksiz ve zamanında ödemeleri, başka bir deyişle vergi ile ilgili görevlerini gönüllü, severek ve isteyerek yerine getirmeleri şeklinde ifade edilebilir (Kahriman, 2016:231). İzaha davet müessesesinin düzenlenmesinin önemli bir amacı da vergiye gönüllü uyumun artırılması ve henüz vergi incelemesine başlanılmamış veya takdir komisyonuna sevk edilmemiş mükellefler için bir çözüm yolu olarak düşünülmüş olmasıdır (Biyan, 2016: 47). İzaha davet ile mükellefe tanınan açıklama yapma hakkı mükellefi vergi ödevini yerine getirmede daha istekli kılabilecektir. Nitekim mükellef vergi ziyanna sebebiyet verecek bir olaya sebep olurken, devlet kendisine derhal cezai işlem uygulamayacak ve mükellefi dinleyecektir. Vergi mükellefleri ile oluşturulacak işbirliği ve güvene dayalı ortam, mükelleflerin vergi ahlakının güçlenmesine sebep olacak ve vergiye gönüllü uyumu artıracaktır (GİB, 2007: 24).

\section{Vergilendirme sürecinde etkinlik ve zaman kazancl;}

Vergilendirme süreci tarh işlemi ile başlayıp devletin vergiyi tahsil etmesi ile son bulmaktadır. Bu süreçte mükelleflerle devlet arasında uyuşmazlık çıkması durumunda, sorun idari ve yargısal çözüm yolları ile çözümlenmeye çalışılmaktadır. Devletin beklentisi uyuşmazlık yargıya intikal etmeden idari yollarla çözümlenmesidir. Çünkü ülkemizde vergi yargısında uyuşmazlıklar oldukça uzun sürede çözüme kavuşmaktadır(Buyrukoğlu, 2016: 168). 
İzaha davet müessesesi ise, vergi incelemesine başlanılmadan ve takdir komisyonuna sevk edilmeden verginin ziyaa uğradığına delalet eden emareler bulunduğuna dair yetkili merciler tarafından yapılmış ön tespitlerle ilgili olarak aynı merciler tarafindan mükelleflerden açılama talep edilmesidir. Bu müessese, yapılan değerlendirmeler sonucunda vergi ziyaına sebebiyet vermediği anlaşılan mükelleflerin konuyla ilgili vergi incelemesine veya takdire sevk edilmesini önlemekte, vergi ziyaına sebebiyet verildiği durumlarda ise belirli şartlar dâhilinde indirimli ceza uygulanmak suretiyle mükellefleri daha ağır müeyyidelerden korumaktadır (Gözlüklü, 2017: 1). Bu açıdan, izaha davet kapsamına alınan konular çerçevesinde izaha davet müessesesinin vergi idaresinin ve yargı organlarının iş yükünü ve zaman kaybını azaltacağı karş1 konulamaz bir gerçektir. Ayrıca, mükellef tarafindan vergi ziyaına sebebiyet verdiğini izah edip 15 gün içerisinde vergi aslının ve vergi ziyaının ödenmesi ile aynı işlemlerin inceleme sonrasında tespit edilmesi sonuçlarını karşılaştırdığımızda kamu gelirleri, tam incelemeler için bir yıl, sınırlı incelemeler için altı ay daha erken bir sürede tahsil edilmiş olacaktır (Başaran, 2016).

\section{Izaha davet neticesinde gerçekleşecek diğer avantajlar;}

- $\quad \mathrm{Bu}$ düzenleme ile mükelleflere vergi ziyaı cezasını indirimli (\%20 oranında) ödeme imkanı getirilmiştir ve mükelleflere tarhiyat sonrası uygulanan ceza konusunda uzlaşma imkanı da tanınmıştır (Öztürk, 2017).

- $\quad$ Ayrıca, "İzaha davet şartlarından herhangi birini taşımadığı anlaşılan mükelleflerin vergi beyannamelerini vermelerine engel bir durum bulunmamakta olup, vergi incelemesine başlanılmadan veya takdir komisyonuna sevk edilmeden beyannamelerini vermiş̧ olanlara, ziyaa uğratılan vergi üzerinden Vergi Usul Kanunu'nun 344. maddesi gereği $\% 50$ oranında vergi ziya1 cezası kesilir (Gezer ve Gezer, 2017).

- 482 Seri No.lu VUK Genel Tebliği'nde, izaha davet müessesesinden yararlanan mükellefin VUK 376. maddesi kapsamında cezada indirim uygulamasından ayrıca yararlanmasını engelleyen bir durum bulunmamaktadır (Gezer ve Gezer, 2017).

- İzaha davet uygulaması yoluyla vergi kaybına neden olmadığı anlaşılan mükelleflerin vergi incelemesi ile gereksiz yere tedirgin edilmesi önlenerek vergi psikolojisi yönünden olumlu bir adım atılmış olacaktır.

- Mükellefler inceleme ve takdir süreçleri sonucunda kendileri adına tarh edilecek vergi ve kesilecek cezaların tutarlarını bilemediklerinde iş hayatlarını gerektiği gibi planlayamaz duruma gelebilmekte, bu süreç içerisinde sonuca kadar geçen süreçte belirsizlikle karş1 karşıya kalmaktadırlar. İzaha davet sonucunda mükelleflerde bu türden negatif durumlarla yüzleşmek durumunda kalmamaktadırlar (Ege, 2017).

\subsection{Dezavantajları}

Mükellefi denetim şekillerinden olan vergi incelemesi stresinden kurtarmak ve minimum seviyede vergi ziyaı cezasına tabi tutmak, idare açısından vergi gelirlerinin biran önce hazineye intikalini sağlamak, ihtilaflı durumların yargıyı meşgul etmeden çözülmesini sağlamak, vergiye gönüllü uyumu sağlamak amaçlarıyla düzenlenmiş olan izaha davet müessesesi ile alakalı dezavantajlardan da bahsetmek kanaatimizce mümkündür.

1 Eylül 2017 tarihinde uygulamaya girmiş olan, vergiye gönüllü uyum için tamamıyla iyi niyetle düşünülmüş, özellikle önümüzdeki dönemlerde uygulama sonrası etkileri daha çok analiz edilebilecek "İzaha davet" bazı eleştirileri de beraberinde getirmektedir.

Bu başlık altında izaha davet uygulamasının mükellef ve devlet açısından dezavantajlarına yer verilecektir. 


\section{Idareye verilen genis yetki;}

Kanunun Maliye Bakanlığı'na verdiği yetkilerle, uygulaması ne kadar sınırlandırılırsa sınırlandırılsın ön incelemede verginin ziyaa uğradığına dalalet eden emarelerin sınırı ve somutluğu netleştirilmedikten sonra, söz konusu izaha davet müessesesi kısmen uygulamada sorunlara yol açabilecektir (Fahran, 2017). Çünkü her türlü kayıtdış1lık, verginin ziyaa uğradığına dalalet eden bir gösterge olup, kayıtdışılığın da somut bir şekilde ölçülemediği göz önüne alındığında, izaha davet müessesesi bu noktada eksik kalacaktır.

Her ne kadar uygulamanın amacı kayıtdışı ekonomiyi önlemek ve kanun gerekçesinde de belirtildiği üzere vergiye gönüllü uyumu arttırmak olsa da Maliye Bakanlığı'na verilen bu yetki yasama yetkisinin devredilemezliği ilkesine aykırıdır (Kılınçkaya, 2017). Birçok kesim tarafından eleştirilen vergi uyuşmazlıklarında idari bir çözüm yöntemi olan uzlaşma müessesesi gibi izaha davet de yasamanın vergilendirme yetkisini zedelemektedir. Bu durum, vergi idarelerinin keyfi hareket etmelerine sebebiyet vererek vergi toplayıcısı olan devlete olan güveni azaltacaktır.

\section{Kapsamda ayrimcilik;}

İzaha davetin kapsamı başlığında belirtilen on altı başlıktan sonuncusu olan sahte veya muhteviyatı itibarıyla yanıltıcı belge kullanılması durumunda ön inceleme sırasında her belgenin 50.000TL'nin altında olması ve mükellefin ilgili yıldaki toplam mal ve hizmet alışlarının \%5'ni aşmıyor olması, izaha davet hükümlerinin uygulanabilmesi için yeterlidir. VUK 359. maddedeki sahte ve muhteviyatı itibariyle yanıltıcı belge kullanma fiili üç kat vergi ziyaı cezası ile cezalandırılmaktadır. Aynı fiil için uygulanacak ceza sadece bu belgenin 50.000TL'nin altında olup olmamasına göre değişmektedir.5732 sayılı Türk Ceza Kanunu 5. maddesinde " $B u$ Kanun'un genel hükümleri, özel ceza kanunlart ve ceza içeren kanunlardaki suçlar hakkında da uygulanacăğ" hükme bağlanmıştır. VUK 359. maddesinde düzenlenen suçlar ve cezalar, Türk Ceza Kanunu genel hükümlerine tabi olduğundan suçu oluşturan eylemlerin gerçekleştiği durumda, ceza kanunu genel hükümleri yerine parasal sınırların aşılmasına bağlı bir düzenleme, ceza hukuku temel ilkelerine aykırılık doğurmaktadır. Ceza hukukunda eşitlik ilkesinden genel anlamda bir eşitlik anlaşılmaktadır. Aynı türdeki suçlarda benzer nitelik ve ağırlıkta cezaların verilmesi gerekliliği eşitlik anlayışından kaynaklanmaktadır (Serim, 1994: 24). Bu ilkelerin çiğnenmiş olması bir dezavantaj ortaya çıkarmaktadır.

\section{Dürüst mükellefleri cezalandırma;}

482 No.lu VUK Genel Tebliği'nde izaha davet yazısı gönderilen mükelleflerin, Vergi Usul Kanunu'nun 371. maddesinde yer alan pişmanlık hükümlerinden yararlanamayacağ belirtilmiştir. Burada ortaya çıkabilecek sorun, verginin ziyaa uğradığına delalet eden emareler bulunduğunda yetkili merciler ön tespit işleminde mükellefi izahat yapmaya çağıracaktır. Ancak pişmanlık hükümleri ve izaha davet müessesi arasında mükellefin seçim şansı yoktur. 213 sayılı VUK 371. maddesinde beyana dayanan vergilerde vergi ziyaı cezasını gerektiren fiilleri işleyen mükelleflerle bunların işlenişine iştirak eden diğer kişilerin kanuna aykırı hareketlerini ilgili makamlara kendiliğinden dilekçe ile haber vermesi halinde, gerekli şartlar altında vergi ziyaı cezası kesilmeyeceği hüküm altına alınmıştır. Yeni getirilen izaha davet uygulamasında ise vergi ziya1 cezası $\% 20$ olarak alınmaktadır. Bu şekilde mükellef aleyhine bir durum söz konusu olabilecektir. Hatta izaha davetle ilgili 482 Sıra No'lu Vergi Usul Kanunu Genel Tebliği uyarınca, tarhiyat sonrası uzlaşma başvurusu da yapılabilir. Tebliğ düzenlemesine göre tarhiyat sonrası uzlaşma komisyonunun uygulamalarına göre cezanın sıfıra kadar indirilmesi imkan dahilindedir. $\mathrm{Bu}$ durum her ne kadar vergi ziyaina neden olan eylemde bulunan mükellef için avantaj içerse de gönüllü uyuma sahip vergisini düzenli ödeyen mükellefler için dezavantajdır.

Vergi uyuşmazlıklarının çözümünde uzlaşma barışçıl bir yöntemdir. Mükellefler üzerindeki etkisi ise farklı olmaktadır. Uzlaşılan mükellefler için olumlu fakat vergisini zamanında ödeyen mükellefler için olumsuz izler bırakmaktadır. Çünkü uzlaşma müessesesi ile 
vergisini ödememiş mükellefler vergi asılları ve cezalarının bir kısmını -belki de hepsini- ödeme yükümlülüğünden muaf olabilmektedir. (Buyrukoğlu, 2016: 166).Görüldüğü üzere izaha davet müessesesi özellikle vergi afları ve uzlaşma gibi vergi uyuşmazlıklarındaki idari çözüm yöntemlerine getirilen eleştirilerde olduğu gibi vergisini düzenli ödeyen mükellefler için gönüllü uyumu azaltacak, idareye olan güven sarsılacak ve konu hakkında yeterli bilgiyi edindikten sonra bu şekilde vergiden kaçınılabilecektir. Bu şekilde devlet her ne kadar gönüllü uyumu arttırmak amacıyla vergi bilinci tam olmayan mükellefleri geri kazanmaya çalışırken, zamanla vergisini tam ödeyen mükellefleri de vergiden kaçınmaya teşvik etmiş olacaktır.

\section{Caydiricillkta zayıflama;}

Kayıtdışı istihdamın kamu idaresinden kaynaklı nedenleri arasında cezanın eşitsizliği ve etkinsizliğini sayabiliriz (Karaaslan, 2010: 53). Vergiye uyum açısından bakıldığında vergi cezaları ve bu cezaların yaptırımları miktar, uygulama, bileşim, af, erteleme ve esasları gibi birçok konuda dâhil olmak üzere ne kadar gerekli olduğu açıktır(Şanver, 2017:104).İzaha davet müessesini incelediğimizde sahte veya muhteviyatı itibarıyla yanıltıcı belge kullanılması durumunda ön inceleme sırasında her belgenin 50.000TL'nin altında olması ve mükellefin ilgili yıldaki toplam mal ve hizmet alışlarının \%5'ni aşmıyor olması şartı getirilmiş olduğunu görmekteyiz.50.000TL'lik fatura düzenlersek faydalanabildiğimiz izaha davetten 50.001 TL'lik fatura düzenlersek faydalanamayacağız. Zamanla mükellefler bu bilgi dâhilinde vergi ziyaina sebebiyet veren fiilleri 50.000TL'lik faturalar olarak düzenlemeye gidecektir. Aslında devlet bu şekilde kanunda belirtilen sınırın altında sahte veya muhteviyatı itibariyle yanıltıcı belge düzenlemeye teşvik etmiş olmaktadır. $\mathrm{Bu}$ şekildeki denetim sistemi caydırıcılığını kaybetmektedir.

\section{Değerlendirme kriteri}

482 No.lu VUK Genel Tebliği'ne göre izaha davet verginin ziyaa uğradığına dalalet eden emareler bulunduğuna dair yetkili merciler tarafından yapılmış ön tespitlerle ilgili olarak aynı merciler tarafından mükelleflerden açıklama talep edilmesidir. Sözü geçen ön tespit 482 No.lu VUK Genel Tebliğinde vergi kanunlarının verdiği yetki kapsamında vergi incelemesi yapmaya ve/veya mükellefler veya mükelleflerle muamelede bulunan diğer gerçek ve tüzel kişilerden bilgi toplamaya yetkili kılınanlar tarafından doğrudan veya dolaylı olarak elde edilen bilgi, bulgu veya verilerin İzah Değerlendirme Komisyonu'na intikal ettirilmesi neticesinde, mezkûr komisyon tarafından verginin ziyaa uğramış olabileceği ve mükellefin izaha davet edilebileceği yönünde yapılan tespiti ifade eder. Bu tespit uygulamada objektif olmayan değerlendirmelerden dolayı karşımıza belirsizlik çıkarabilecektir. Aynı şekilde izahatın yeterli olup olmamasıyla alakalı verilecek kararlarda matematiksel ve somut veriler dişında kalan, net olmayan alanlarda objektif karar vermek zorlaşacak izaha davet müessesesinde etkinlik sağlamakta sıkıntı çekilebilecektir.

\section{Kapsam;}

Maliye Bakanlığı izaha davetin kapsamını 482 Sıra No.lu Vergi Usul Kanunu Genel Tebliğinin 2. maddesinde on altı başlık olarak belirlemiştir. Bu başlıklar 1şığında, izaha davet müessesesi, "verginin ziyaa uğradiğına delalet eden emareler" olarak açıķa belirtildiğinden sadece vergi ziyaını kapsadığını, genel ve özel usulsüzlüklerin ise kapsam dışı bırakıldığını görmekteyiz. Vergi uyuşmazlıklarının çözümünde uygulanan diğer barışçıl yöntemlerden olan uzlaşma, cezada indirim, hata düzeltme ve pişmanlık ve 1slah uygulamalarının vergi ziyaının yanı sıra usulsüzlükleri de kapsamasına rağmen izaha davet uygulamasının sadece vergi ziyaı cezasını kapsaması bir eksiklik olarak görülebilir. Bu durum ise vergi cezasına sebep olan mükelleflerin tamamına hitap edilememesine neden olacak ve mükellefler arasında ayrımcılığa sebebiyet verebilecektir. Ayrıca, kapsam daha geniş tutulursa vergi cezasına muhatap olan ve 
cezayı ödemeyi düşünmeyen mükellefleri teşvik ederek devletin daha fazla gelir elde etmesine katk1 sağlanacağından kapsamın genişletilmesi gerektiği düşünülmektedir.

\section{SONUÇ}

Vergi uyuşmazlıklarının ç̧̈zümünde yeni bir barışçıl yöntem olan izaha davet müessesesi gerek devlet gerekse mükellefler adına da oldukça önemli bir gelişmedir. $\mathrm{Bu}$ uygulama ile mükelleflere kendilerini ifade etme, devlete ise gelirlerini biran önce hazineye intikal etme şansı tanınmış olacaktır. Nitekim vergi uyuşmazlıklarının yargıya intikal ettiği düşünüldüğünde uzun yargı süreci sonucunda devletin vergi gelirleri enflasyon karşısında değer kaybedebilecektir. Mükellefler ise, yargı sürecinin aleyhine sonuçlanması durumunda vergi borcunun yanında gecikme zammı/faizi ile daha fazla ödeme yapmak zorunda kalacaktır. Böylece, usulüne uygun işleyen izaha davet müessesesi neticesinde hem devlet hem de mükellef kazançlı çıkacaktır.

Mali anlamda hem devletin hem de mükellefin kazançlı çıktığı izaha davet müessesesi mali olmayan unsurlar açısından incelendiğinde ise yine bir takım avantajlara sahipken, ciddi sorunlar doğurabilecek olumsuzluklara da sahiptir.

Vergi bilinci açısından izaha davet uygulaması hem avantaj hem de dezavantaj olarak görülebilir. Çünkü mükellefe tanınan açıklama yapma hakkı mükellefi vergi ödevini yerine getirme konusunda daha istekli kılabilecekken, vergisini düzenli ödeyen mükellefler açısından vergiye gönüllü uyumu azaltacak ve idareye olan güven sarsılacaktır.

Vergilendirme sürecinde etkinlik ve zaman kazancı ise devlet açısından en önemli avantajdır. İzaha davet kapsamına alınan konular çerçevesinde izaha davet müessesesinin vergi idaresinin ve yarg1 organlarının iş yükünü ve zaman kaybını azaltacağı karşı konulamaz bir gerçektir.

İzaha davet ile mükelleflerin indirimli (\%20 oranında) ödeme yapması, VUK 376. maddesi kapsamında cezada indirim uygulamasından ayrıca yararlanmasinı engelleyen bir durum bulunmamas1, mükelleflerin vergi incelemesi ile gereksiz yere tedirgin edilmesi önlenerek vergi psikolojisi yönünden olumlu bir adım atılmış olması ise bu uygulamanın diğer avantajları olarak sayılabilir.

482 Sıra No'lu Vergi Usul Kanunu Genel Tebliği uyarınca Maliye Bakanlığı ön tespitin niteliğini, izaha davetin şeklini ve kapsamını, daveti yapacak ve yapılan izahı değerlendirecek mercii, davet yapılacakları, yapılan izahta kullanılacak bilgi ve belgeler ile uygulamaya ilişkin usul ve esasları belirlemeye yetkilidir. Maliye Bakanlığı'na verilen bu yetki yasama yetkisinin devredilemezliği ilkesine aykırıdır. Bu durum ise, yasama organının vergilendirme yetkisini zedelemektedir.

İzaha davet uygulamasının sadece on altı konu başlığını taşıması eleştirilebilecek bir diğer husustur. Hangi konularla ilgili olarak izaha davet müessesesinin uygulanacağı Maliye Bakanlığı tarafından belirlenmekte ve 482 Sıra No'lu Vergi Usul Kanunu Genel Tebliğinde neden sadece on altı konu başlığı olduğuna ilişkin bir açıklama mevcut değildir.

İzaha davetin değerlendirilmesine ilişkin uygulama da bir sorun olarak karşımıza çıkmaktadır. İlgili değerlendirme İzah Değerlendirme Komisyonu tarafından yapılmaktadır. Bu komisyon, vergi incelemesi yapmaya yetkili kılınanlar tarafindan bilgilendirilmekte ve komisyon tarafından verginin ziyaa uğramış olabileceği ve mükellefin izaha davet edilebileceği belirlenmektedir. Bu uygulama ise keyfiliğe gayet açık bir uygulamadır.

İzaha davet müessesesi, sadece vergi ziyaını kapsamakta iken genel ve özel usulsüzlükler ise kapsam dışı bırakılmıştır. Vergi uyuşmazlıklarının çözümünde uygulanan diğer 
barışç1l yöntemlerden olan uzlaşma, cezada indirim, hata düzeltme ve pişmanlık ve 1slah uygulamalarının vergi ziyaının yanı sıra usulsüzlükleri de kapsamasına rağmen izaha davet uygulamasının sadece vergi ziyaı cezasını kapsaması bir eksiklik olarak görülebilir.

Sonuç olarak, izaha davet uygulaması 482 Sıra No'lu Vergi Usul Kanunu Genel Tebliğdeki ayrıntıları ile hayatımıza girmiştir. Oldukça yeni bir uygulama olması nedeniyle yukarıda belirtilen avantaj ve dezavantajlar bu uygulamaya ilişkin öngörüler olup, zaman içerisinde uygulama sonuçları neticesinde daha somut verilere ulaşılabilecektir.

\section{KAYNAKÇA}

Başaran, K. (2016). Türk vergi sisteminde yeni uygulama: izaha davet. E-Yaklaşım, 287.

Biyan, Ö. (2016). İdari aşamada yeni bir çözüm yolu: izaha davet. Bilanço, 162, 46-49.

Buyrukoğlu, S. (2016). Vergi bilincinin zedelenmesinde devlet faktörü. Vergi Sorunlarl, 331, 161-169

Çetin, G. ve Gökbunar, R. (2010). Mükellef haklarına vergi idaresi çalışanlarının bakış1, Yönetim ve Ekonomi,1, 2346.

Ege, F. (2017). İzaha davet üzerine. E-Yaklaşım, 298.

Fahran, F. (2017). Türk vergi sisteminde geçmişte izaha davet ile ilgili yasal düzenlemeler ve son düzenleme. EYaklaşım, 289.

Gezer, A. ve Gezer,Y. (2017). Vergi uygulamalarında yeni bir müessese "izaha davet” ve etkinliği. E-Yaklaşım, 298.

GİB (2007). Türkiye’de Mükelleflerin Vergiye Bakışı, Ankara: Gelir İdaresi Başkanlığı, Mükellef Hizmetleri Daire Başkanlığı, Yayın No: 51.

Gözlüklü, B. (2017). Vergilendirme işlemlerinde yeni dönem: “izaha davet”, CentrumAuiting, 1-6.

İşbilir, Ş. (2008). Türkiye'de vergi uyuşmazlıkları ve idari çözüm yolları, Yayınlanmamış Yüksek Lisans Tezi, Trakya Üniversitesi, Sosyal Bilimler Enstitüsü, Edirne.

Kahriman, H. (2016). Vergiye gönüllü uyum çerçevesinde Türkiye'de gelir idaresinin organizasyon yapısı üzerine bir değerlendirme. Ekonomik ve Sosyal Araştırmalar, 1, 229-250.

Karaaslan, E. (2010). Türkiye'de kayıtdışı istihdam ve neden olduğu mali kayıpların bütçe üzerindeki etkileri: Türkiye örneği. Mali Hizmetler Derneği, Yayın No: 7, Ankara.

Kılınçkaya, L. (2017). İzaha davet yasası nerden buldun yasasının isim değiştirmiş hali mi? E-Yaklaşım, 290.

Serim, B. (1994). Yasa önünde eşitlik ilkesi. Amme İdaresi, 27, 13-25.

Şanver, C. (2017). Türk vergi sisteminde vergi kabahat ve suçlarına uygulanan yaptırımların caydırıcılığı araştırması. Yönetim Bilimler, 29, 91-106.

Türkay, İ. (2013). Türk vergi idaresinde mükellef odaklı yaklaşım-mükellef hakları-vergiye gönüllü uyum uygulamaları. Vergi Sorunlarl, 299, 148-163.

Öztürk, N. (2017). “İzaha davet” müessesesi uygulamaya geçiyor. E-yaklaşım,297.

6728 sayılı Yatırım Ortamının İyileştirilmesi Amacıyla Bazı Kanunlarda Değişiklik Yapılmasına Dair Kanun; 09/08/2016 tarihli ve 29796 sayılı Resmi Gazete'de yayımlanmıştır.

482 Sıra No.lu Vergi Usul Kanunu Genel Tebliği; 25/07/2017 tarihli ve 30134 sayılı Resmi Gazete'de yayımlanmıştır. 
Optimum Journal of Economics and Management Sciences, Vo1. 5, No. 1- http://dergipark.ulakbim.gov.tr/usakoeyb/ Buyrukoğlu and Toparlak - Invitation to View Method with Advantages and Disadvantages 